Volume 15. Nomor 1. June 2020 Page 1-12
Pandecta
http://journal.unnes.ac.id/nju/index.php/pandecta

\title{
Are BUMN/State-Owned Enterprises (SOES) Hybrid Organizations?
}

\section{Yuli Indrawati ${ }^{1}$}

Faculty of Law, Universitas Indonesia, Indonesia

DOI: http://dx.doi.org/10.15294/pandecta.v15i1.24193

\begin{abstract}
Article info
Abstract

Article History:

Received : January 52020

Accepted: May 52020

Published: June 152020

The organization is now well developed. The organization does not only consist of public and private organizations, but also mixed organizations (hybrid organizations). And it's influence to the organizations of State-Owned Enterprises (SOEs) as stated in the legal considerations of Constitutional Court (MK) Decision Nr. 48 and

Keywords:

State-Owned Enterprises;

hybrid organizations; 62 / PUU-XI /2013 that exclaims that SOEs are private legal entities that carry out public duties. Referring to this matter, (a) elements of hybridity in SOEs, (b) benefits and risks in the form of hybrid SOE organizations, (c) the concept of hybridity in increasing the achievements of SOE objectives. By using an analytical approach and legislation results that based on the characteristics of BUMNs are categorized as hybrid organizations. As a hybrid organization has benefits and risks as a result of the influence of the public and private elements. The greatness of the benefits and risks of hybrid organizations is inversely proportional to the size comparison of public and private elements. The hybrid concept at Perum (Public Company) which aims for public benefit is a balanced public element with a private element. Whereas for Persero (State Company) that has commercial aims, the private element must be more dominant to create flexibility that drives the development of the Company. It is recommended that the concept of hybridity in SOEs must be adapted to the form of the company and the objectives of the company.
\end{abstract}




\section{Introduction}

Today, with the rapid development in society requires changes in various ways where there is no clear separation between one another and no longer clashed as something contradictory. This also happens in institutions, where organizations not only take the form of public organizations and private organizations, but also mixed organizations (hybrid organizations) as a combination of public and private organizations. In practice it was found that even this hybrid organization had several variations, namely (1) hybrid organizations with more public element contents than private contents, (2) hybrid organizations with balanced contents between public and private elements, and (3) hybrid organizations with contents less public element than its private contents. Variants of public element contents will affect the nature and work procedures of the management of the BUMN itself which of course also has an impact on the performance of the BUMN. In Indonesia, there are SOEs in the form of Persero and Perum with their respective characteristics. Thus, to optimize SOE performance so that the objectives of SOE formation are achieved, the content of the public element must be synergized with the form of SOE itself - it not generalized.

In legal considerations of the Constitutional Court Decision Number 48 / PUU-XI / 2013 regarding the review of Article 2 letter g and $i$ of Law Number 17 of 2003 concerning State Finance, among others, it states that "SOE is an extension of the government in carrying out government functions in broad meaning. ...... from this perspective and the function of the legal entity concerned cannot be fully considered a private legal entity. "Then in legal considerations in the Decision of the Constitutional Court Number 62 / PUU-XI / 2013 concerning the testing of Article 9 paragraph (1) letter b, Article 10 paragraph (1), and paragraph (3) letter b, and Article 11 letter a of Law Number 15 of 2006 concerning the Supreme Audit Board, it is stated among other things that "BUMN, BUMD, or other similar names are (i) business entity belonging to the state, (ii) its function is to carry out business as a derivation and control the livelihoods of many people and Indonesia's natural resources, (iii) most or all of the business capital comes from separated state finances, and (iv) to achieve the greatest prosperity of the people. Based on this conclusion, BUMN, BUMD, or other similar names are different from private legal entities that also carry out business on the one hand and are also different from state organs which do not conduct business, such as state institutions and ministries or agencies."

Based on legal considerations in the two Constitutional Court decisions, acknowledging the existence of a public element from SOEs as an extension of the state carrying out public duties and also at the same time recognizing the existence of private elements from SOEs as a business entity.

Several previous studies have linked the implications of capital paid by the State to SOEs with the state's position on SOEs. Jimly Asshiddiqie (Asshiddiqie, 1994) stated that the granting of capital by the state to SOEs must be seen as implementing the right of the state to control economic potential in accordance with the mandate of Article 33 of the 1945 Constitution, and not because the owner is the people. As the ruler, the State carries out regulatory actions regarding the BUMN in general, and does not manage the BUMN. Next Dian P.N. Simatupang (Simatupang, 2011) stated that SOEs are ordinary civil legal entities established by the State based on civil law construction. The state must comply with the provisions of civil law, namely as a shareholder in the same position as other shareholders. A different view was expressed by Milo Kamal (Putusan MK, 2013) who used the theory of the principal agency, namely the state's position in the SOE was as an acting principal representing the people (because state money came from the people), while the directors were agents or executors. Therefore the State is the true owner of the BUMN. The expert who used the perspective of the organization was Muchsan who stated that "SOEs are semi-public institutions, meaning that they do have public or private characteristics" (Putusan MK, 2013). 
Therefore to this thesis, the issues raised in this thesis are (a) how can SOEs be categorized as hybrid organizations?, (b) how are the benefits and risks of hybrid SOE organization forms?

\section{Method}

To answer the issues raised in this thesis, an analytical and regulatory approach is used. This approach method can produce research that is accurate and very strong level of truth (Ibrahim, 2006). Analytical approach is used to find out the meaning contained in legislation related to BUMN. While the statutory approach is used because this research is based on various laws and regulations which will be studied comprehensively, all-inclusive, and systematic. This is intended to gain new meaning in the existing rules and test them based on the factual conditions of implementing SOE governance and their implications for SOE performance.

To get answers to the questions above, the following will describe the development of organizations starting from private organizations and public organizations until the birth of hybrid organizations including things that influence or underlie the formation of these third types of organizations. Furthermore, the laws and norms relating to the nature of hybrid SOEs and the factual management of SOEs are explained in order to understand the elements of hybridity in SOEs, the benefits and the risks of hybrid elements in SOEs. The magnitude of public and private elements in a hybrid organization creates diversity with the characteristics and benefits and risks of each. The description of this will support the analysis of the benefits and risks of the hybrid form of organization towards the achievement of the objectives of SOEs, given the existence of two types of SOEs, namely the Public Company (Perum) and the Company Company (Persero). The right amount for every kind of BUMN will certainly maximize the performance of BUMN so that it can play a role in the development of the nation and state.

\section{Result and Discussion}

\section{Hybrid Organizations}

Classically there are two kinds of organizations namely private organizations and public organizations (Rainey, 1998). Based on the nature of the organization, private legal entities are private organizations, while ministries are public organizations. At that time, the division of macroeconomic work between the state (government) and the private sector was carried out simply where each focused on their respective goals. The state (government) concentrates on the implementation of the functions of public services and the interests of the people through the provision of public goods, while the private sector carries out commercial economic activities that provide private goods (Atika, 2013).

Research conducted by Billis, there are several elements that distinguish an organization, namely (Billis, 2010):

"A private sector which is (a) owned by shareholders and (b) governed according to the principle of size of share ownership, (c) working according to operational priorities driven by principles of market forces in individual choice, with typical (d) human resources consisting of paid employees in a managerially controlled firm and (e) other resources primarily from sales and fees.

A public sector which is (a) owned by the citizens and (b) governed according to principles of public elections, (c) with work driven by principles of public services and collective choice and as its typical (d) human resources consisting of paid public servants in legally backed bureaux and (e) resourced by taxation."

In its development, strict differentiation of the characteristics of each organization can no longer be maintained because now there has been a change, where public and semipublic goods are no longer a government monopoly, but became the land of market and private mechanisms. On the other hand, the State also experienced a change in role, not only providing public goods, but also producing private goods. So as to create a new form of organization that is in the middle. Such organizations are known in the United 
States as mixed organizations or hybrid organizations, whereas in Commonwealth countries referred to as quangos (Koppel, 2003).

Hybrid organizations are often said to occur because of a change in the paradigm of government management, in which there has been an all-shifting state towards the private sector in terms of public services (Evers, 2005). In fact, hybrid organizations existed long before he realized the dominance of the country's role. For example, a number of private banks in the world were once given the authority to print money and circulate money. For example, the Bank of England in the United Kingdom, the Riksbank in Sweden, the De Nederlansche Bank in the Netherlands, the National Bank of Copenhagen (National Bank of Denmark) in Denmark, and the De Javasche Bank in the Dutch East Indies (Rahardjo, 1995). Before finally, the bank's status was changed to a central bank (owned by the government). In terms of funding, the bank's capital comes in part from the private sector and partly from the government. In addition to carrying out the tasks assigned by the state, this private bank also continues to carry out activities as well as ordinary private banks, namely conducting commercial banking activities. The assignment of public tasks to banks is done in two ways namely, given to existing institutions (private banks) or formed new institutions with this pattern. In Indonesia alone, hybrid organizations have been known since the Dutch occupation era namely the VOC and De Javasche Bank.

More common than quangos or American-style hybrids around the world are large numbers of hybrids as state enterprises, public enterprises or state-owned enterprises. These businesses owned entirely or in part by governments and generally were founded as private companies. The appeal of hybrids, entities that combine characteristics of public- and private-sector organizations, lies in the belief that they combine the best of both worlds: public accountability and private efficiency (Koppel, 2003).

Hybrid organizations are born as a result of the strengths and weaknesses of each form of organization (Rainey, 1998). By combining public and private elements in an organization, it is hoped that there will be an increase in strengths and minimize weaknesses from the previous form of organization. There is no standard formula about the magnitude of the public element compared to the private element in hybrid organizations. Research conducted by L.T. Christensen (Christensen, 2017) at the state railroad companies in Swedish and Danish in the 1990-2015 period showed the evolution of the governance of state-owned enterprises (SOEs) in passenger rail services. Using institutional change theory, the paper shows how the SOEs' hybrid character changed over time. The political responsibility for the Danish SOE expanded, while the Swedish SOE's political role was gradually reduced. Although there is no standard formula for public content on hybrid organizations, research conducted by Karré on three companies in Dutch Waste Management in the Netherlands, illustrates the correlation between the magnitude of the public element on the performance and progress of SOEs. BUMN which has a greater private element is able to develop its company on a par with other private companies. Whereas organizations with larger public elements do not develop as advanced as organizations with larger private elements (Karre, 2011).

For instance, for state-owned enterpri-

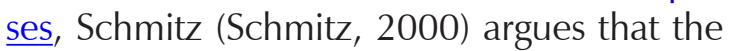
combination of public and private interests brings an optimal combination of incentives for reducing costs and improving quality in comparison with pure production forms. In contrast, Voorn, Van Genugten, and Van Thiel (Bart Voorn, 2017) hypothesize that diversity of ownership may lead to benefits such as specialization and increased efficiency, but also downsides such as increased failure rates.

Incentives to act aggressively toward competitors can be created by governmental policy objectives that induce SOEs to value an expanded operating scale. To illustrate, SOEs are often instructed to increase local employment and/or to ensure that affordable service is provided ubiquitously to low-income families. Such directives can blunt in- 
centives for profit maximization, and thereby introduce a system in which the success of the manager of an SOE is measured more by the scale and scope of his operations than by the profit that his operations generate. Under such an explicit or implicit reward structure, SOEs may act as if they value expanded scale and scope-as proxied by revenue, for example-as well as, or instead of, profit. The enhanced valuation of increased revenue or expanded output lead the SOE to be less averse to the higher costs associated with expanded output and revenue. In aggressively pursuing expanded scale and enhanced revenues, SOEs may find it advantageous to engage in anti-competitive behavior against private, profit-maximizing enterprises (Sidak, 2003).

Karré argues that the benefits and risks of having a public element in hybrid organizations can be seen from four points of view, namely economics, performance, cultural, and governance (Riberio, 2005). Here are the advantages of having a public element in hybrid organizations:

1. Economic benefits: hybridity can benefit an organization's financial and economic position by for example getting access to new markets;

2. Performance related benefits: hybridity can also have a positive effect on an organization's performance, as it can serve an incentive to increase effectivity;

3. Cultural benefits: hybridity is by its advocates seen as an incentive to combine the best of both worlds by bringing the most prominent values of the public and the private sector together. This, they expect, will help make public sector organizations more customer-oriented;

4. Governance related benefits: hybridity is by its advocates seen to have a positive effect on an organization's relationship with its political principals and, via these representatives, also with society as a whole.

While the risks as a result of the pre- sence of a public element in hybrid organizations are as follows.

1. Economic risks: these concern various forms of unfair competition, such as the use of cross-subsidies, the use of confidential government data for commercial means, the forming of public monopolies and the combination of conflicting roles;

2. Performance related risks: because hybridity, the critics claim, organizations will neglect their public tasks in favour of their commercial activities;

3. Cultural risks: hybridity can lead to cultural conflicts as private sector values are introduced which are commonly seen to be stronger than public sector values as they are based on individual self-interest rather than on altruism. Conflict can arise when an organization attracts new employees with a commercial background who (because of their expertise) earn more than its veteran staff;

4. Governance related risks: putting an organization at arm's length and following it to enter the market place, the critics claim, will lead to it developing an own identity and opportunistic behavior. As hybrid organizations mostly focus on their own interests, they become less dependable partners for their political principals in the provision of public services.

Then what about the condition of BUMN in Indonesia as a hybrid organization?

\section{BUMN as a Hybrid Organization}

The main basis for the government to establish SOEs is Article 33 paragraph 2 of the 1945 Constitution which regulates that business branches that are important to the State and control the lives of many people are controlled by the State and are used for the greatest prosperity of the people. This article is a justification for the government to establish SOEs. The purposes and objectives of establishing a BUMN are (a) contributing to the development of the national economy 
in general and state revenue in particular; (b) the pursuit of profit; (c) organizing public benefits in the form of providing goods and / or services of high quality and sufficient for the fulfillment of the lives of many people; (d) pioneering business activities that cannot yet be carried out by the private sector and cooperatives; (e) actively giving guidance and assistance to entrepreneurs of economically weak groups, cooperatives, and the community (Article 2 paragraph (1) of Law Number 19 of 2003 concerning State-Owned Enterprises (UU BUMN)).

The presence of SOEs in Indonesia began with the nationalization of foreign companies. Law Number 86 of 1958 concerning the Nationalization of Dutch Companies. Many state-owned companies currently originate from Dutch companies (both stateowned and private companies) that were nationalized by the Indonesian government in the post-independence period, especially in 1957, when a severe economic crisis occurred (Achmad, 1963). Some examples include Telkom, Pelni, Train and Plantation. The Dutch BUMNs in those years played an important role in Indonesia's economic life. The country at that time needed income from the business sector not only to overcome the economic crisis but also to finance the administration of government (Wahyuni, 2010).

When the government established SOEs in Indonesia, these companies had two main tasks, namely as a driver of national development and as a state-owned business unit. As a driver of national development, SOEs were established to meet the needs of the public that are not in demand by the private sector (because it requires a very large investment or because of high business risks) (Wrihatnolo, 2008), and builds a very strategic industry because it deals with state security (for example Pindad, Dahana, Peruri, etc.). Based on the above, many of the needs of the Indonesian people are provided in a monopoly manner by SOEs, such as telecommunications, transportation, housing, banking, insurance, clean water, and others (Nugraha, 2002). As a state-owned business unit, SOEs are expected to be a source of state revenue (commercial goals) to finance governance and achieve the state's goals.

Until now, SOEs still play an important role in the development of the national economy and as a source of state revenue. Based on data from the Ministry of SOEs, as of the end of 2018, there were 114 SOEs in the form of Public Corporation of 14 and 100 in the form of Persero engaged in 15 business sectors.

Even institutionally, SOEs continue to develop, and finally SOEs have only two forms, namely Public Corporation (Perum) and Persero (Persero). Following are the characteristics of BUMN based on Law No. 19 of 2003 concerning State Owned Enterprises (UU BUMN), which also distinguishes between the Public Corporation and Persero, namely:

\section{Capital}

BUMN capital comes from the State, in whole or in part. In Perum, all capital comes from the State (Article 1 number 4), whereas at Persero, the State capital is at least 51\% and is divided into shares (Article 1 number 2)

\section{Establishment}

The purpose of the establishment of BUMN, distinguished between Perum and Persero. The purpose of Perum is for public benefit in the form of providing high quality goods and / or services and at the same time pursuing profits based on company management principles (Article 1 number 4), while the main purpose of the Persero is to pursue profits (Article 1 number 2).

\section{SOE governance.}

Public Corporation is managed with the principle of a healthy company (Article 1 number 4). In Perum, the Minister holds a central role in Perum governance, including the authority to approve long-term plans, work-budget plans, annual reports, as well as policies related to Perum governance proposed by directors.

Specifically for Persero, the principles applicable to Limited Liability Companies (Article 11) apply. In the case that the com- 
pany is a public company, it is also subject to regulation in the capital market (Article 34). The highest organ at the Persero is the General Meeting of Shareholders (GMS). Articles 21 and 22 stipulate that it is the responsibility of the directors to draft a long-term plan and the company's work-budget plan as the formalized by the GMS. After the financial year is closed, the directors are obliged to submit a report to the GMS for approval (Article 23).

Filling in the directors' positions.

In Perum (Articles 45 and 46), directors are appointed and dismissed by the Minister. Members of the board of directors are appointed based on consideration of expertise, integrity, leadership, experience, honesty, good behavior, and high dedication to advance and develop Public Corporation.

Pursuant to Articles 15 and 16 of the appointment and dismissal of Persero's directors are conducted by the GMS. Members of the board of directors are appointed based on consideration of expertise, integrity, leadership, experience, honesty, good behavior, and high dedication to advance and develop the Company.

Based on the characteristics of these SOEs, public and private elements can be identified. For Public Corporation, the public element is reflected in (a) capital which is entirely paid up by the State and (b) the purpose of Public Corporation, namely for the supply of goods to the public. While the civil element is in (1) governance and (2) appointment / dismissal of directors. Perum governance is carried out applying the principles of sound corporate governance. The Minister represents the government as the owner of capital. Therefore the minister's authority in terms of governance must be interpreted by the minister as the owner of capital - not representing public power. Thus, entering into the civil law environment. In addition, the private element is reflected in the directors' obligation to make long-term plans and company work-budget plans. This reflects the concept of civil law. In the case of appointment and dismissal of directors reflect the principle of ordinary civil com- pany that is carried out by the highest organ of the company. Likewise, the requirements for becoming a member of the board of directors are determined based on the needs of the company - as applied to ordinary civil companies. Based on the identification of the characteristics of Public Corporation, Public Corporation contains elements of public and civil elements. Therefore, Public Corporation is included in the category of hybrid organizations.

For Persero, the analysis that can be given based on the characteristics of the Company, as follows. Persero's capital is based on a stock alliance. Even though the state is the majority shareholder, the position of the state here is as a shareholder, having the same position as other shareholders. This is a concept of private organization. Furthermore, in terms of the objectives of the Persero, it is clear that its nature is commercial, namely the pursuit of profit. This is also the concept of private organization. However, referring to Article 2 paragraph (1) of the SOE Law concerning the purpose and objectives of establishing SOEs, among others (d) pioneering business activities which cannot yet be carried out by the private sector and cooperatives; (e) actively providing guidance and assistance to entrepreneurs of the economically weak, cooperative, and community groups reflecting the existence of a public element. Therefore towards the objectives of the Persero it can be said that there are private goals and also public goals. In terms of governance, Persero is subject to governance in limited liability companies which in fact are private organizations - where the highest organ is the GMS. Likewise in the case of appointment / dismissal of directors, they must obtain endorsement from the GMS. Therefore, referring to the characteristics of the Company based on the BUMN Law, the corporation can be categorized as a hybrid organization.

As stated earlier, the formation of hybrid organizations is based on weaknesses and strengths in each traditional form of organization. Hybrid organizations are formed with the intention of combining the strengths of public and private organizations, to mini- 
mize the weaknesses of the two organizations. The following is a review of the benefits and risks of SOEs as a hybrid organization using Karre's classification (the data used to analyze the benefits and risks come from laws and regulations and facts related to the application of norms of legislation in factual conditions).

1. Economic benefits: With the provisions in Article 2 letter $g$ of Law Number 17 Year 2003 concerning State Finance (State Finance Law) which states that state assets separated from SOEs are included in the scope of state finances, making SOE funding can be fully dependent on the state. SOEs does not need to think about funding issues, just ask the State if additional funding is needed. This is illustrated by comparing the amount of state capital participation in SOEs in the 2010 State Budget with the 2014 State Budget (before and after the Constitutional Court's decision to establish BUMN as a hybrid organization). State investment in SOEs in the 2010 State Budget was IDR 602 trillion and in the 2014 State Budget was IDR 1,091 trillion. Increasing the number of state capital participation in BUMN shows that the state is used as a reliable source of funds to increase BUMN capital.

2. Performance related benefits: various incentives are received by SOEs such as tax breaks, import duties, monopoly and exceptions to general arrangements. This can increase effectiveness. This should provide advantages for SOEs compared to private companies.

3. Cultural benefits: The implementation of public tasks by an organization in the form of a company has a positive impact on society, because the provision of goods and / or services is better than if carried out by a public organization.

4. Governance related benefits: SOEs receive various protections, monopolies, reliefs and facilities that benefit the company because it is an extension of the government.

As for the weaknesses of the existence of a public element in SOEs is as follows.

1. Economic risks: (a) SOEs depending on the state for funding, with limited state budget (APBN), is actually an obstacle for SOEs to obtain the maximum funding in accordance with what is needed, because the allocation of the state budget must still be shared for other activities that become the duties and obligations of the state, so that the portion that can be given to increase BUMN capital is not in accordance with the SOE funding needs themselves. (b) BUMNs for certain business fields (related to the livelihoods of many people or natural resources) carry out activities which are monopolistic and do not recognize market competition (Pangestu, 1996). On the one hand, this monopoly will enable SOEs to carry out activities exclusively, but on the other hand this exclusive nature will bring disaster because quality is often forgotten and innovation is underdeveloped. For example, when telecommunications are still carried out are monopolized by SOEs, the quality provided is not optimal, but when opportunities are opened for similar activities by other parties, then the quality becomes better and innovation begins to be activated. (c) Various incentives and facilities received by SOEs create unfair competition in the market for other companies (Hartono, 2014). This of course also has a negative effect on the development of economic activities. (d) The number of (public) rules imposed on SOEs imposes and limits SOE competitiveness compared to the provisions imposed on other private companies. For example the settlement of bad loans for state-owned banking sector, even though the Constitutional Court's decision Nr. 77/PUU-IX/2012 which states that SOE receivables are not state receivables, the banks are reluctant to do their own settlement for 
fear of being charged with corruption (Harris, 2007), so that the settlement of bad loans cannot be done simply following the procedures applicable to private companies, but more complex and a long time because they have to follow the procedures that apply to government agencies, so it becomes protracted.

2. Performance related risks: the position of SOEs in Indonesia which is between the socio-political-economic interests of the country (public tasks that must be carried out) and the interests of companies (as private organizations that have commercial purposes to seek profits), thus resulting in the interests of companies being defeated by reasons 'in the public interest'. "This creates a dilemma for SOEs, where often commercial goals cannot coincide with social goals, so BUMN performance is not optimal" (Sidik, 2014).

3. Cultural risks. Compared between SOEs and private companies, it can be seen that SOEs have weaknesses which culturally pose risks as follows. (a) The bureaucratic culture in SOEs results in weak work orientation in SOEs. (b) The values of good corporate governance are very minimal. Activities do not refer to customer-oriented. (c) Opening up opportunities for moral hazard, because management is more concerned with protecting himself against corruption charges against business actions he does than profit orientation (Hartono, 2014). Even though it has been stated in the consideration of the Constitutional Court's decision No. 62 / PUU-XI / 2013 that the paradigm that applies to SOEs is business judgment rules, not government judgment rules, it still gives a negative aura and fear for company leaders in making business decisions, because they are overshadowed by demands criminal acts of corruption (in some cases criminal convictions for directors and their staff related to state losses / corruption, for example the case of Neleo the director of PT Bank Mandiri who got entangled in a bad credit case, Hotase Nababan the director of PT Merpati, who was entangled in a case of embezzlement by a third party in a lease agreement (Muntaqo, 2018)).

4. Governance related risks. Protecting national interests is often used as a reason for the state to intervene, among others in the form of: (a) Political influence, especially in the election of the president director of SOEs, makes SOEs inseparable from political interests in conducting their business activities (no economic autonomy). (b) State intervention on dividends that are the right of the state (due to budget deficits) reduces the ability of SOEs to develop their business activities. (c) Business decisions are often the result of a commercial and social-politicaleconomic compromise of the country. (d) In addition, many BUMNs must eventually set aside a lot of funds for the benefit of political parties, especially in the period leading up to the election.

Based on the description above related to the elements of hybridity in SOEs based on the BUMN Law and analysis of the benefits and risks of SOEs as a hybrid organization based on the State Finance Law and factual data, the analysis will then be elaborated on the concept of SOEs hybridity in increasing achievement of SOE objectives. This concept was arranged in accordance with the form of BUMN namely Perum and Persero.

In accordance with the analysis of the hybridity element at Perum, the public and private elements at Perum based on the BUMN Law are balanced. This concept is in accordance with the objective of establishing a Public Corporation which is thick with social content. The private element is needed to maintain business continuity without burdening the State and improving service quality. While the public element is needed to maintain the availability of services and ensure the affordability of services for the community. Each element must be applied cor- 
rectly.

Unlike the case with Persero. Based on the norms in the BUMN Act, Persero has a private element that is more dominant than the public element. This is important to increase the flexibility of the Company in managing and developing its business. If this concept is implemented, the objectives of the Persero can be achieved optimally. However, based on the norm in the State Finance Law which states that SOE finance is included in the scope of state finance has implications for the relationship between the state and companies, in the form of non-corporate intervention (Didu, 2018). Non-corporate interventions can be in the form of political interventions, interventions of fiscal interests, and legal interventions. Place Persero as a corporation, apply corporate principles in corporate governance, so that the objectives of establishing a Persero can be optimal. The Persero's public element must be interpreted as a special assignment from the State, which of course must be based on corporate management practices. The special assignment must be clear and contained in the work contract, both in terms of the tasks that must be performed, its governance, and financing. In addition to ensuring that the task is carried out well, it also avoids state intervention in the Company by taking refuge in special assignments. Other non-corporate interventions must be completely eliminated. Thus, the Company can provide an optimal contribution as a generator of passion for the development of the national economy and also as a contributor to dividends and tax that is qualified for the country. So that the era of BUMN that burdens the state budget will pass and is replaced by the era of BUMN as the main pillar of receiving state budget.

\section{Conclusion}

Based on the above analysis of the questions raised in this thesis, it is concluded as follows.

SOEs, both Perum and Persero, based on characteristics created based on norms in the BUMN Law, can be categorized as hybrid organizations. The characteristics used are capital, organizational goals, governance, and appointment / termination of directors. In the Public Corporation, the public and private elements are balanced. The public element of Public Corporation includes capital and purpose of Public Corporation. While the private element is in the governance and appointment / dismissal of directors. At Persero, the public element is found in the specific objectives of SOEs which contain social content. The Persero's private elements are reflected in the Company's capital, Persero's objectives, Persero's governance and appointment / termination of directors. Thus, the private element at Persero is more dominant than the public element.

Benefits and risks of SOEs as hybrid organizations use economic, performance, cultural and governance indicators. The benefits are (a) funding is sufficient to rely on Government funds; (b) a number of incentives provided by the State to SOEs can increase company effectiveness; (c) people get more benefits from the availability of public goods; and (d) facilities obtained due to the strong relations between BUMN and the Government. The risks include (a) lack of capacity to develop as a result of limited Government funds; (b) weakening quality; (c) creating unfair competition with private companies; (d) reduce company flexibility because of the many binding rules compared to private companies; (e) conflicts of interest between commercial goals and social goals; ( $(f)$ creating bureaucratic management that undermines performance, (g) is not consumer oriented, (h) opens opportunities for moral hazard, (i) no economic autonomy, (j) non-corporate interventions in the form of political intervention, fiscal intervention, and legal intervention.

The concept of hybridity which is suitable for optimizing the achievement of SOE objectives must be distinguished according to the form of the company. For Public Corporation which aims for public benefit, the concept of hybridity offered is a balance between public and private elements. This is important to keep the objectives of the Public Corporation optimally achieved. Unlike the 
case with Persero that have commercial goals, the public element must be less - even limited. Place Persero as a corporation, apply corporate principles in corporate governance, and eliminate non-corporate interventions. So that the Company can achieve maximum profits.

The suggestion that can be given is that the concept of hybridity in SOEs must be adapted to the form of the company and the company's goals. The level of hybridization only results in the non-optimal functioning of the BUMN, so the benefits for the people are not optimal.

\section{References}

Achmad, S. (1963). The Dynamics of The Nationalization of Dutch-Owned Enterprises in Indonesia: a Political, Legal, Economic Development and Administrative Anaysis. Indiana: Indiana University.

Asshiddiqie, J. (1994). Gagasan Kedaulatan Rakyat Dalam Konstitusi dan Pelaksanaannya di Indonesia. Jakarta: Ichtiar Baru.

Atika, D. B. (2013, Juli-Desember). Pelayanan Publik Berkarakter Prima: Sebuah Pendekatan Teoritik. Jurnal Ilmiah Administrasi Publik dan Pembangunan, 4(2).

Bart Voorn, M. L. (2017). The efficiency and effectiveness of municipial owned corporations: a systematic review. Local Government Studies, 43(5), 820-841. doi:10.1080/03003930.2017 .1319360

Billis, D. (2010). Hybrid Organization and the Third Sector: Challenges for Practice, Theory and Policy. In D. Billis (Ed.), Hybrid Organization and the Third Sector: Challenges for Practice, Theory and Policy (pp. 46-69). Basingstoke, UK: Palgrave.

C. Skelcher, N. M. (2005). The Public Governance of Collaborative Spaces: Discourse, Design and Democracy. Public Administration, 83 (3), 573596.

Christensen, L. (2017). How Hybridity has Evolved in the Governance of State-Owned Enterprises: Evidence from Danish and Swedish Passanger Rail Services from 1990 to 2015. Public Money and Management, 37 (6), 401-408. doi:https:// doi.org/10.1080/09540962.2017.1344016

Cooney, K. (2006). The Institutional and Technical Structuring of NonProfit Ventures: Case Study of a U.S. Hybrid Organization Caught Between Two Fields. Voluntas, 17(1), 143-161.

Didu, M. S. (2018). BUMN sebagai Benteng Pertahanan Ekonomi Nasional dan Buffer Perekonomian Rakyat. Bincang Seru. Jakarta.

Evers, A. (2005). Mixed Welfare Systems and Hybrid Organizations: Changes in the Governance and Provision of Social Services. International Jour- nal of Public Administration, 28 (1), 737-748.

Fitriani, I. (2011). Pola Pengelolaan Badan Usaha Milik Negara Sebuah Potret Singkat. Manajerial, 10(2), 19, 54-75.

Gidron, Y. H. (2005). Undrstanding Multi-Purpose Hybrid Voluntary Organizations: The Contributions of Theories on Civil Society, Social Movements and Non-Profit Organizations. Journal of Civil Society, 1(2), 97-112.

Hamid, E. S. (1999). Peran dan Intervensi Pemerintah dalam Perekonomian. Jurnal Ekonomi Pembangunan, 4(1), 41-58.

Harris, F. (2007). Kedudukan Negara sebagai Penyertaan Modal dalam PT Persero: Pengubahan Ketentuan yang Tidak Sesuai Dengan Prinsip-prinsip Hukum Perusahaan. Jakarta: Disertasi Program Pascasarjana Fakultas Hukum Universitas Indonesia.

Hartono, D. (2014). Tinjauan Keuangan Negara dari Perpsektif Hukum Perseroan dan Economic Analysis of Law. In Y. Indrawati (Ed.), Aktualisasi Hukum Keuangan Publik (pp. 227-250). Bandung: Mujahid Press.

Ibrahim, J. (2006). Teori dan Metodologi Penelitian Hukum Normatif. Malang: Bayumedia.

Indrawati, Y. (2014). Economic Analysis of Law (EAL) atas Ketentuan Pasal 2 huruf g Undang-Undang No. 17 Tahun 2003 tentang Keuangan Negara. In Y. Indrawati (Ed.), Aktualisasi Hukum Keuangan Publik (pp. 251-268). Bandung: Mujahid Press.

Karre, P. M. (2009). Boundary Spanning in Practice Consequences of Working on The Border Between Public and Private. International Conference: Towards Knowledge Democracy. Leiden.

Karre, P. M. (2011). Heads and Tails: Both Sides of The Coin, An Analysis of Hybrid Organizationz in The Dutch Waste Management Sector. Den Haag: Eleven International Publishers.

Kasim, H. (2016). Memikirkan Kembali Pengawasan Badan Usaha Milik Negara Berdasarkan Business Judgement Rules. Jurnal Konstitusi, 14(2), 441.

Khairandy, R. (2009). Korupsi di Badan Usaha Milik Negara Khususnya Perusahaan Perseroan: Suatu Kajian atas Makna Kekayaan Negara yang Dipisahkan dan Keuangan Negara. Jurnal Hukum, 16(1), 73-87.

Koppel, J. G. (2003). The Politics of Quasi-Government, Hybrid Organizations and The Dynamics of Bureaucratic Control. Cambridge: Cambridge University Press. Retrieved from www.cambridge. org/9780521525602

Muntaqo, M. Z. (2018, Desember). Penerapan Prinsip Detournemen de Pouvoir Terhadap Tindakan Pejabat BUMN yang Mengakibatkan Kerugian Negara Menurut Undang-Undang Nomor 17 Tahun 2003 tentang Keuangan Negara. Nurani, 18(2), 177-194.

Nugraha, S. (2002). Privatisasi di Berbagai Negara. Jakarta: Lentera Hati.

Pangestu, M. (1996). Economic Reform, Deregulation and Privatization. 
Powell, W. (1987). Hybrid Organizational Arrangements: New Form or Transitional Development? California Management Review, 30(1), 67-87.

Putters, T. B. (2005). Griffins or Chameleons? Hybridity as a Permanent and Inevitable Characteristic of the Third Sector. International Journal of Public Administration, 28(1), 749-765.

Putusan MK, Nomor 48/PUU-XI/2013 (Mahkamah Konstitusi 2013).

Rahardjo, M. D. (1995). Bank Indonesia Dalam Kilasan Sejarah Bangsa. Jakarta: LP3ES.

Rainey, J. P. (1998). The Public-Private Distinction in Organization Theory: a Critique and Research Strategy. The Academy of Management Review, 13(2), 182-201.

Riberio, P. M. (2005). The Social Profit of Hybrid Service Delivery. EGPA Conference. Berne.

Rothschild-Whitt, J. (1979). The Collective Organization: an Alternative to Rational-Bureaucratic Models. American Sociological Review, 44(1), 509-527.

Saragih, J. P. (2014). Politik dan Ekonomi Kebijakan Privatisasi Badan Usaha Milik Negara. Jurnal Ekonomi dan Pembangunan, 22(1), 83-105.

Schmitz, P. W. (2000). Partial Privatisation and Incomplete Contrats: The Propoer Scope of Government Reconsidered. FinanzArchiv, 57(1), 394411.

Sidak, D. E. (2003). Competition Law for State-Owned
Enterprises. Antitrust Law Journal, 71(2), 479523.

Sidik, M. (2014). Analisis Peran Badan Usaha Milik Negara dalam Pembangunan, Keuangan Negara dan Kinerjanya sebagai Korporasi. In Y. Indrawati (Ed.), Aktualisasi Hukum Keuangan Publik (pp. 269-316). Bandung: Muhajid Press.

Simatupang, D. P. (2011). Paradoks Rasionalitas Perluasan Ruang Lingkup Keuangan Negara dan Implikasinya Terhadap Kinerja Keuangan Pemerintah. Jakarta: Badan Penerbit FHUI.

Spear, C. C. (2010). The Governance of Hybrid Organisations. In D. Billis (Ed.), Hybrid Organizations and The Third Sector: Challanges for Practice, Theory and Policy (pp. 70-89). Basingstoke, UK: Palgrave.

Sumarni. (2013). Intervensi Pemerintah antara Kebutuhan dan Penolakan di Bidang Ekonomi. ECONOMICA Journal of EConomic and Economic Education, 1(2), 183-194. doi:http://dx.doi. org/10.22202/economica.2013.v1.i2.118

Taco Philip Bradsen, M. K.-K. (2009). The Risks of Hybrid Organisation: Expectations and Evidence. NISPACEE Conference. Budva.

Wahyuni, E. (2010). Kebijakan dan Manajemen Privatisasi BUMN/BUMD. Yogyakarta: Yayasan Pembaruan Administrasi Publik Indonesia.

Wrihatnolo, R. N. (2008). Manajamen Privatisasi BUMN. Jakarta: Gramedia. 